CORRECTION

\title{
Correction to: Reconsidering our focus on innovation: What are the effects of innovation on well-being?
}

\section{David A. Griffith ${ }^{1}$}

Published online: 16 September 2021

(c) Società Italiana Marketing 2021

\section{Correction to: Italian Journal of Marketing https://doi.org/10.1007/s43039-021-00038-5}

The article has been published with an incorrect copyright, it is updated now.

The original article has been corrected.

Publisher's Note Springer Nature remains neutral with regard to jurisdictional claims in published maps and institutional affiliations.

The original article can be found online at https://doi.org/10.1007/s43039-021-00038-5.

David A. Griffith

dgriffith@mays.tamu.edu

1 Mays Business School, Texas A\&M University, College Station, TX, USA 